\title{
MENUMBUHKAN NILAI-NILAI KEPAHLAWANAN DI LINGKUNGAN MAHASISWA
}

\author{
Muawanah \\ Sekolah Tinggi Agama Buddha Negeri Sriwijaya \\ punyamuawanah@gmail.com
}

\begin{abstract}
The purpose of cultivating the values of heroism in the student environment is to establish an attitude and behavior of students struggle to build the nation and state of Indonesia through the value of sacrificial, homeland love, hard work, exemplary, honesty, democratic, independently and responsible which must be integrated in daily life. The steps to cultivate the values of heroism in the student environment is: to instill a sense of "love of the homeland" and "democratic" through the race based on national insight; inculcate "willingness to sacrifice", "responsible" and "hard work" through the program of group dynamics competence; instill a sense of "self-reliance" in students; and instilling "honesty" in students. The method used in this writing is a qualitative descriptive study method of literature study. It is expected that with heroic values possessed, students can build their nation and state so that to the advanced and quality nation and state.
\end{abstract}

Keywords: values, heroism, students.

\section{Pendahuluan}

Bangsa Indonesia saat ini sedang menapaki dan melanjutkan pembangunan di segala sektor. Belum bisa dipastikan risiko atau gangguan yang akan dihadapi, tetapi satu hal yang sudah pasti ialah adanya derajat ketidakpastian dan semakin tingginya kompleksitas permasalahan. Menghadapi hal tersebut, yang diperlukan adalah tidak hanya merapatkan barisan di antara pelaku-pelaku pembangunan, tetapi juga perlu upaya peningkatan pengertian dan kesadaran di masyarakat luas akan perannya dalam wujud menerapkan nilai-nilai kepahlawanan dalam kehidupan seharihari. Nilai-nilai kepahlawanan bisa berupa cinta tanah air, rela berkorban, dan berani membela kebenaran untuk kepentingan bangsa dan negara. Nilainilai tersebut relevan pada masa kini untuk menjaga kesatuan dan persatuan bangsa khususnya bagi generasi muda yaitu mahasiswa.

Mahasiswa dapat dikatakan sebuah komunitas unik yang berada di masyarakat, dengan kesempatan dan kelebihan yang dimilikinya, mahasiswa mampu berada pada posisi di atas masyarakat. Mahasiswa juga belum tercekoki oleh kepentingan-kepentingan suatu golongan, organisasi masyarakat, partai politik, dan lain sebagainya. Berdasarkan potensi dan kesempatan yang dimiliki oleh mahasiswa, tidak sepantasnyalah bila mahasiswa hanya mementingkan kebutuhan dirinya sendiri tanpa memberikan kontribusi terhadap bangsa dan negaranya. Mahasiswa sudah 
bukan siswa yang tugasnya hanya belajar, bukan pula rakyat, bukan pula pemerintah. Mahasiswa memiliki tempat tersendiri di lingkungan masyarakat, namun bukan berarti memisahkan diri dari masyarakat. Untuk itu perlu dirumuskan perihal peran, fungsi, dan posisi mahasiswa untuk menentukan arah perjuangan dan kontribusi mahasiswa tersebut terhadap bangsa dan negaranya. Oleh karena itu, dipandang perlu untuk menumbuhkan nilai-nilai kepahlawanan pada mahasiswa agar mampu berperan dan berkontribusi terhadap bangsa dan negaranya.

Nilai merupakan gambaran mengenai apa yang diinginkan, pantas, berharga, dan mempengaruhi perilaku sosial dari yang memilih nilai itu (Lawung, 2009: 22). Ini merupakan gagasan yang mengesankan mengenai pengamalan yang berarti atau tidak dan mencapai hasil akhir yang menjadi pedoman untuk merancang suatu perubahan. Mengenai makna kepahlawanan tidak lepas dari kata dasarnya yaitu pahlawan. Menurut KBBI kepahlawanan merupakan perihal sifat-sifat pahlawan (keberanian, keperkasaan, kerelaan berkorban, dan kesatria). Menurut Roeslan Abdulgani kepahlawanan adalah jiwa berbakti untuk mendapat pahala Tuhan. Kepahlawanan merupakan sikap bakti kepada manusia, bangsa, maupun tanah air dalam mewujudkan kehidupan yang adil dan sejahtera. Ada beberapa nilai-nilai kepahlawanan yang berada di Indonesia, di antaranya: nilai rela berkorban, cinta tanah air (nasionalisme), kesatria, patriotisme, kejujuran, keberanian, gotong-royong, mandiri, bertanggung jawab, dan tanpa pamrih.

Bicara tentang nilai-nilai kepahlawanan tidak lepas pada peristiwa 10 November 1945. Para pemuda pada saat itu dengan gagah berani menentang kolonialisme di negeri ini. Para pahlawan berjuang membela tanah air dengan tanpa pamrih, tidak bergantung pada siapa pun, dan mempunyai tanggung jawab yang sangat tinggi dalam mempertahankan kemerdekaaan dan martabat bangsa. Sifat-sifat seperti inilah yang sangat diperlukan bagi para generasi muda khususnya mahasiswa untuk menghadapi penjajahan arus globalisasi dan kapitalisme di Indonesia saat ini. Dampaknya banyak membawa kaum muda pada budaya-budaya baru yang tentu perlu adanya antisipasi pada diri kaum muda, agar tidak terjerumus pada budaya-budaya yang menghilangkan karakter bangsa. Berdasarkan hal tersebut, masyarakat Indonesia setiap tanggal 10 November memperingatinya sebagai Hari Pahlawan. Sosok para generasi muda spesifiknya mahasiswa harus mampu mengaktualisasi nilai-nilai kepahlawanan dalam setiap tindakannya.

Untuk melaksanakan nilai-nilai perjuangan kepahlawanan dalam kehidupan sehari-hari dapat dimulai dari lingkup terkecil, yaitu keluarga. Menanamkan semangat berkorban, disiplin, kebersamaan, dan motivasi untuk berprestasi bagi keluarga merupakan nilai-nilai yang dapat diaplikasikan dalam keluarga. Menanamkan nilai kepahlawanan dari lingkup terkecil dapat dimulai dari memberi pemahaman arti penting tentang pengabdian, pengorbanan, kerja keras, dan mengerti kepentingan orang 
banyak, bukan kepentingan pribadi. Namun, untuk dapat memenuhi upaya itu tidak mudah. Keinginan menerapkan nilai-nilai perjuangan kepahlawanan dalam kehidupan bermasyarakat mengalami sejumlah hambatan (https://nasional.kompas.com/read/2016/11/08/05280001/arti.kepahlawanan.p ada.masa.kini).

Di masa kini, makna pahlawan dapat diartikan sebagai seseorang yang menonjol karena mempunyai jiwa yang berani, rela berkorban, dan tidak hanya mementingkan diri sendiri. Banyak profesi bisa dikategorikan pahlawan, seperti guru, aktivis lingkungan hidup, dan relawan kemanusiaan. Perilaku berpartisipasi dalam aksi-aksi kemanusiaan sangat layak dikategorikan sebagai tindakan kepahlawanan. Sikap meningkatkan taraf hidup sosial ekonomi masyarakat juga dianggap sebagai sikap yang pantas disebut sebagai tindakan kepahlawanan. Sikap lainnya, yakni tindakan antikorupsi atau antisuap, dinilai sebagai tindakan pahlawan (https://nasional.kompas.com/read/2016/11/08/05280001/arti.kepahlawanan.p ada.masa.kini).

Sikap-sikap yang telah diabadikan sebagai nilai-nilai kesatria penuh pengorbanan tulus ikhlas kepahlawanan Indonesia terdahulu telah mewujudkan Negara Kesatuan Republik Indonesia (NKRI) menuju kemerdekaan dan perdamaian abadi hingga saat ini. Kemerdekaan NKRI atas pengorbanan dan usaha penuh para pahlawan bangsa telah membawa perubahan besar bagi berdirinya NKRI dan perkembangannya hingga saat ini dapat dirasakan oleh bangsa Indonesia masa kini.

Indonesia masa kini mengalami perubahan ke arah kemerosotan moral. Nilai-nilai kepahlawanan yang diilhami dari sikap kepahlawanan terdahulu seperti: rela berkorban, cinta tanah air, kerja keras, keteladanan, kejujuran, demokratis, mandiri, dan bertanggung jawab, tak lagi tampak dalam perspektif karakter bangsa Indonesia masa kini. Bangsa Indonesia masa kini mengalami degradasi nilai kepahlawanan. Hal tersebut ditandai dengan munculnya sikap egoisme bangsa Indonesia yang kini hanya mementingkan kepentingan pribadi dan golongan tertentu dengan mengorbankan persatuan dan kesatuan. Dengan adanya karakter bangsa yang telah diuraikan tersebut, dapatlah dirasakan pada saat ini dengan banyaknya kecurangan, ketidakadilan, kemiskinan dan hal-hal lain yang menurunkan kesejahteraan bangsa Indonesia dan dapat membawa Indonesia dalam kehancuran.

Dalam rangka memperbaiki serta melangkah menuju Indonesia yang lebih baik, pertama-tama karakter harus dibangun melalui upaya menumbuhkan nilai-nilai kepahlawanan di lingkungan mahasiswa terlebih dahulu. Hal tersebut dapat mempengaruhi pola hidup bangsa sehari-hari dalam pembangunan Indonesia. Dengan adanya realita tersebut, penulis mengangkat judul "Menumbuhkan Nilai-Nilai Kepahlawanan di Lingkungan Mahasiswa”. 


\section{Pembahasan}

Menumbuhkan berasal dari kata dasar tumbuh. Menumbuhkan adalah sebuah homonim karena artinya memiliki ejaan dan pelafalan yang sama tetapi maknanya berbeda. Menumbuhkan memiliki arti dalam kelas verba atau kata kerja sehingga menumbuhkan dapat menyatakan suatu tindakan, keberadaan, pengalaman, atau pengertian dinamis lainnya (htttps://www.apaarti.com/menumbuhkan.htm/).

Menurut Kamus Besar Bahasa Indonesia, menumbuhkan adalah verba (kata kerja) yakni: (1) menjadikan (menyebabkan) tumbuh; (2) memelihara dan sebagainya supaya tumbuh (bertambah besar, sempurna, dan sebagainya); memperkembangkan; dan (3) menimbulkan (kebencian, perselisihan, dan sebagainya). Berdasarkan pengertian tersebut, yang dimaksud menumbuhkan dalam artikel ini adalah menjadikan (menyebabkan) tumbuhnya sikap-sikap pahlawan pada diri mahasiswa.

\section{Nilai-Nilai Kepahlawanan}

Nilai merupakan gambaran mengenai apa yang diinginkan, pantas, berharga, dan mempengaruhi perilaku sosial dari yang memilih nilai itu ( Lawung, 2009: 22). Ini merupakan gagasan yang mengesahkan mengenai pengamalan yang berarti atau tidak dan mencapai hasil akhir yang menjadi pedoman untuk merancang suatu perubahan. Nilai mempunyai pengertian kumpulan sikap perasaan ataupun anggapan terhadap sesuatu hal mengenai baik-buruk, benar-salah, patut-tidak patut, mulia-hina, maupun penting atau tidak penting (Tim Sosiologi Yudhistira, 2003: 99). Nilai adalah gagasan mengenai apakah pengalaman berarti atau tidak berarti, nilai juga mengarahkan perilaku dan pertimbangan seseorang dalam mengambil keputusan (Paul B. Horton \& Chester L. Hunt, 1999: 71).

Nilai adalah sesuatu yang berharga, bermutu, menunjukkan kualitas, dan berguna bagi manusia. Sesuatu dikatakan bernilai jika berharga atau berguna bagi kehidupan manusia. Adanya dua macam nilai tersebut sejalan dengan penegasan Pancasila sebagai ideologi terbuka. Perumusan Pancasila sebagai ideologi terbuka terdapat dalam pembukaan UUD 1945 alinea 4 dinyatakan sebagai nilai dasar dan penjabarannya sebagai nilai instrumental. Nilai dasar tidak berubah dan tidak boleh diubah lagi. Betapa pun pentingnya nilai dasar yang tercantum dalam Pembukaan UUD 1945 itu, sifatnya belum operasional. Artinya, belum dapat dijabarkan secara langsung dalam kehidupan sehari-hari. Penjelasan UUD 1945 sendiri menunjuk adanya undang-undang sebagai pelaksanaan hukum dasar tertulis itu (Paulus Wahana, 2004: 122).

Dari penjelasan di atas dapat disimpulkan bahwa nilai adalah sesuatu yang penting, baik, dan berharga. Dalam nilai terkandung sesuatu yang ideal, harapan yang dicita-citakan untuk kebajikan. Menilai berarti menimbang suatu kegiatan, menghubungkan sesuatu dengan yang lain dan kemudian mengambil keputusan. Sesuatu dianggap punya nilai jika sesuatu itu 
dianggap penting, baik, dan berharga bagi kehidupan umat manusia, baik ditinjau dari segi religius, politik, hukum, moral, etika, estetika, ekonomi maupun sosial budaya.

Pengertian kepahlawanan tidak bisa dilepaskan dari pengertian kata pahlawan itu sendiri. Menurut Susilo Bambang Yudhoyono, pahlawan diartikan sebagai sosok orang (biasa) yang tidak egois dan berbuat sesuatu yang luar biasa, memiliki tindakan atau perbuatan (pengorbanan) untuk orang lain, dan adanya penghormatan sebagai imbalan atas pengorbanannya (http://www.dpdimmriau.co.cc/2009/01/teorinilai.html).

Menurut Roeslan Abdulgani kepahlawanan adalah jiwa berbakti untuk mendapat pahala Tuhan. Kepahlawanan berinti kebaktian kepada kemanusiaan, bangsa, rakyat, dan kepada tanah air, mengabdi untuk mewujudkan cita-cita keadilan sosial. Jiwa kepahlawanan tidak mengenal ukuran besar atau kecil, melainkan diukur dari unsur keikhlasan dan kesungguhannya. Kepahlawanan tidak hanya lahir dari kancah pertempuran, tetapi dapat juga lahir di kesunyian ruang laboratorium, dari lingkungan pabrik-pabrik yang pengap karena polusi, serta pengabdian seorang guru di daerah terpencil. Ukuran kepahlawanan bisa saja berubah sejalan dengan penyikapan masyarakat terhadap nilai kepahlawanan, namun nilai asasi (intrinsik) tetap bertahan (www.radarbanten.com).

Mengenai makna kepahlawanan tidak lepas dari kata dasarnya yaitu pahlawan. Menurut KBBI kepahlawanan merupakan perihal sifat-sifat pahlawan (keberanian, keperkasaan, kerelaan berkorban, dan kesatria). Kepahlawanan merupakan sikap bakti kepada manusia, bangsa, maupun tanah air dalam mewujudkan kehidupan yang adil dan sejahtera. Adapun kepahlawanan adalah suatu sikap dan perilaku perjuangan yang mempunyai mutu dan jasa pengabdian serta pengorbanan terhadap bangsa dan negara (www.depsos.go.id). Nilai-nilai kepahlawanan, seperti nilai rela berkorban, cinta tanah air, kerja keras, keteladanan, kejujuran, demokratis, mandiri, dan bertanggung jawab harus diintegrasikan dalam pendidikan karakter. Setiap mata pelajaran di sekolah bisa menjadi sarana penanaman nilai-nilai kepahlawanan tersebut, terutama mata pelajaran Pendidikan Kewarganegaraan (PPKn), Sejarah, Ilmu Sosial, dan Bahasa Indonesia (Sudarmanto, 2006: 25).

Nilai-nilai kepahlawanan merupakan salah satu hal yang harus diteladani dan dijadikan contoh, karena seiring perkembangan zaman tidak jarang orang semakin menjadi individualistis (Henk Schulte, 2008: 172). HalHal yang dimaksud dengan nilai-nilai kepahlawanan adalah: (a) rela berkorban yaitu bersedia dengan ikhlas, senang hati, dengan tidak mengharapkan imbalan, dan mau memberikan sebagian yang dimiliki sekalipun menimbulkan penderitaan bagi dirinya; (b) cinta tanah air yaitu perasaan cinta terhadap bangsa dan negaranya sendiri; (c) kerja keras yaitu berusaha dengan sepenuh hati dengan sekuat tenaga untuk berupaya mendapatkan keinginan pencapaian hasil yang maksimal pada umumnya; (d) 
keteladanan yaitu suatu sikap positif yang dapat dijadikan sebagai acuan oleh masyarakat; (e) kejujuran yaitu keserasian atas berita yang disampaikan dengan fakta yang ada; (f) demokratis yaitu suatu pilihan sebuah bangsa menganut paham kebebasan berpendapat dengan hasil musyawarah mufakat; (g) mandiri yaitu melakukan suatu hal tanpa menggantungkan diri pada individu lain; dan (h) bertanggung jawab yaitu keadaan wajib menanggung segala sesuatu hal yang telah diperbuat.

\section{Mahasiswa}

Menurut Kamus Besar Bahasa Indonesia, mahasiswa adalah pelajar perguruan tinggi. Di dalam struktur pendidikan Indonesia, mahasiswa menduduki jenjang satuan pendidikan tertinggi. Sepanjang sejarah, mahasiswa di berbagai negara mengambil peran penting dalam sejarah suatu negara. Misalnya, di Indonesia pada Mei 1998, ratusan ribu mahasiswa berhasil mendesak Presiden Soeharto untuk mundur dari jabatannya. Mahasiswa dapat dikatakan sebuah komunitas unik yang berada di masyarakat, dengan kesempatan dan kelebihan yang dimilikinya, mahasiswa mampu berada pada posisi di atas masyarakat. Mahasiswa juga belum tercekoki oleh kepentingan-kepentingan suatu golongan, organisasi masyarakat, partai politik, dan lain sebagainya.

Menurut Sarwono (1978: 17), mahasiswa adalah setiap orang yang secara resmi terdaftar untuk mengikuti pelajaran di perguruan tinggi dengan batas usia sekitar 18 - 30 tahun. Mahasiswa merupakan suatu kelompok dalam masyarakat yang memperoleh statusnya karena ikatan dengan perguruan tinggi. Mahasiswa juga merupakan calon intelektual atau cendekiawan muda dalam suatu lapisan masyarakat yang sering kali sarat dengan berbagai predikat. Mahasiswa memiliki posisi dan peran sebagai agent of change, social controler, dan the future leader. Mahasiswa sebagai bagian dari kaum muda dalam tatanan masyarakat yang pasti terlibat langsung dalam setiap fenomena sosial, harus mampu mengimplementasikan kemampuan keilmuannya dalam akselerasi perubahan dan perkembangan ilmu pengetahuan dan teknologi ke arah berkeadaban.

Berdasarkan berbagai potensi dan kesempatan yang dimiliki, mahasiswa tidak seharusnya hanya mementingkan kebutuhan dirinya sendiri tanpa memberikan kontribusi terhadap bangsa dan negaranya. Mahasiswa sudah bukan siswa yang tugasnya hanya belajar, bukan pula rakyat, bukan pula pemerintah. Mahasiswa memiliki tempat tersendiri di lingkungan masyarakat, namun bukan berarti memisahkan diri dari masyarakat. Oleh karena itu, perlu dirumuskan perihal peran, fungsi, dan posisi mahasiswa untuk menentukan arah perjuangan dan kontribusi mahasiswa tersebut.

Peran, fungsi, dan posisi mahasiswa dalam masyarakat (Sarwono, 1978: 21) adalah agent of change, social control, iron stock, moral force, dan guardian of value. Mahasiswa sebagai agen dari suatu perubahan. Artinya, jika ada sesuatu yang terjadi di lingkungan sekitar dan itu salah, mahasiswa dituntut untuk 
mengubah sesuai dengan harapan sesungguhnya. Dengan harapan bahwa suatu hari mahasiswa dapat menggunakan disiplin ilmunya dalam membantu pembangunan Indonesia untuk menjadi lebih baik ke depannya. Sebagai generasi pengontrol seorang mahasiswa diharapkan mampu mengendalikan keadaan sosial yang ada di lingkungan sekitar. Jadi, selain pintar dalam bidang akademis, mahasiswa juga harus pintar dalam bersosialisasi dan memiliki kepekaan terhadap lingkungan. Mahasiswa diupayakan agar mampu mengkritik, memberi saran, dan memberi solusi jika keadaan sosial bangsa sudah tidak sesuai dengan cita-cita dan tujuan. Mahasiswa harus memiliki kepekaan, kepedulian, dan kontribusi nyata terhadap masyarakat sekitar tentang kondisi aktual. Sebagai tulang punggung bangsa di masa depan, mahasiswa diharapkan menjadi manusia tangguh yang memiliki kemampuan dan akhlak mulia yang nantinya dapat menggantikan generasi sebelumnya di pemerintahan kelak. Intinya mahasiswa itu merupakan aset, cadangan, harapan bangsa untuk masa depan Indonesia. Mahasiswa sebagai penjaga stabilitas lingkungan masyarakat, diwajibkan untuk menjaga moral yang ada. Bila di lingkungan sekitar terjadi hal-hal yang menyimpang dari norma yang ada, maka mahasiswa dituntut untuk mengubah dan meluruskan kembali sesuai dengan apa yang diharapkan. Mahasiswa sendiri pun harus punya moral yang baik agar bisa menjadi contoh bagi masyarakat dan harus bisa mengubah ke arah lebih baik jika moral bangsa sudah sangat buruk, baik melalui kritik secara diplomatis ataupun aksi. Mahasiswa sebagai guardian of value artinya penjaga nilai-nilai. Sesuai dengan artinya mahasiswa berperan sebagai penjaga nilai-nilai positif.

Tugas perguruan tinggi adalah membentuk insan akademis, yang selanjutnya hal tersebut akan menjadi sebuah fungsi bagi mahasiswa itu sendiri. Insan akademis itu sendiri memiliki dua ciri yaitu memiliki sense of crisis dan selalu mengembangkan dirinya. Insan akademis harus memiliki sense of crisis yaitu peka dan kritis terhadap masalah-masalah yang terjadi di sekitarnya saat ini. Hal ini akan tumbuh dengan sendirinya bila mahasiswa itu mengikuti watak ilmu, yaitu selalu mencari pembenaran secara ilmiah. Dengan mengikuti watak ilmu tersebut maka mahasiswa diharapkan dapat memahami berbagai masalah yang terjadi dan terlebih lagi menemukan solusi yang tepat untuk menyelesaikannya. Insan akademis harus selalu mengembangkan dirinya sehingga mereka bisa menjadi generasi yang tanggap dan mampu menghadapi tantangan masa depan.

Mahasiswa dengan segala kelebihan dan potensinya tentu saja tidak bisa disamakan dengan rakyat dalam hal perjuangan dan kontribusi terhadap bangsa. Mahasiswa pun masih tergolong kaum idealis, hal ini karena keyakinan dan pemikiran mahasiswa belum dipengaruhi oleh partai politik, organisasi masyarakat, dan lain sebagainya. Oleh karena itu, mahasiswa dapat dikatakan memiliki posisi di antara masyarakat dan pemerintah. 
Mahasiswa dalam hal hubungan masyarakat ke pemerintah dapat berperan sebagai kontrol politik, yaitu mengawasi dan membahas segala pengambilan keputusan beserta keputusan-keputusan yang telah dihasilkan sebelumnya. Mahasiswa pun dapat berperan sebagai penyampai aspirasi rakyat, melalui interaksi sosial dengan masyarakat dilanjutkan dengan analisis masalah yang tepat maka diharapkan mahasiswa mampu menyampaikan realita yang terjadi beserta solusi ilmiah dan bertanggung jawab dalam menjawab berbagai masalah yang terjadi di masyarakat.

Mahasiswa dalam hal hubungan pemerintah ke masyarakat dapat berperan sebagai penyambung lidah pemerintah. Mahasiswa diharapkan mampu membantu mensosialisasikan berbagai kebijakan yang diambil oleh pemerintah. Tak jarang kebijakan-kebijakan pemerintah mengandung banyak salah pengertian dari masyarakat, oleh karena itu tugas mahasiswa harus menerjemahkan maksud dan tujuan berbagai kebijakan tersebut agar mudah dimengerti masyarakat.

Posisi mahasiswa cukup rentan, sebab mahasiswa berdiri di antara idealisme dan realita. Tak jarang mahasiswa berat sebelah, saat mahasiswa membela idealisme ternyata melihat realita masyarakat yang semakin buruk. Saat mahasiswa berpihak pada realita, ternyata secara tak sadar sudah meninggalkan idealisme dan juga kadang sudah meninggalkan watak ilmu yang seharusnya dimiliki. Contoh kasusnya yang paling gampang adalah saat terjadi kenaikan harga BBM.

Perjuangan yang dilakukan mahasiswa kini sudah kehilangan esensinya, sehingga masyarakat sudah tidak menganggapnya suatu harapan pembaruan lagi. Di sisi lain, golongan atas seperti pengusaha, dokter, dan lain sebagainya merasa sudah tidak ada lagi kesamaan gerakan. Perjuangan mahasiswa kini sudah berdiri sendiri dan tidak lagi satu napas bersama rakyat.

\section{Menumbuhkan Nilai-Nilai Kepahlawanan di Lingkungan Mahasiswa}

Pascarevolusi, semangat kepahlawanan seperti sudah mendarah daging pada jiwa mahasiswa. Hal ini terlihat jelas pada upaya mahasiswa dalam mempertahankan kemerdekaan dan ikut andil membangun bangsa dan negaranya dengan susah payah. Akan tetapi, akibat perkembangan ilmu pengetahuan dan teknologi serta arus globalisasi yang semakin deras, dapat dilihat perkembangan mahasiswa saat ini hanya menjadi objek oportunisme, dan sering kali termanfaatkan oleh pertarungan politik, ekonomi, sosial, dan budaya. Mahasiswa dipandang sebagai target konsumen globalisasi, mereka mulai dijajankan dengan gaya hidup yang hedonis dan budaya konsumerisme. Budaya yang dibawa oleh arus globalisasi dan modernisasi yang menenggelamkan mahasiswa dari nilai-niliai kepahlawanan.

Melihat keadaan mahasiswa yang semakin memprihatinkan, maka diperlukan adanya penafsiran baru nilai-nilai kepahlawanan yang harus tetap tertanam sebagai jati diri mahasiswa Indonesia. Di era sekarang nilai-nilai 
kepahlawanan bukan lagi diwujudkan dengan perang fisik, mengangkat senjata di medan pertempuran seperti era revolusi. Akan tetapi, bentuk kolonialisme zaman revolusi dengan kolonialisme saat ini sudah jelas berbeda. Bentuk kolonialisme saat ini bukan lagi berbentuk perang fisik, akan tetapi cenderung pada penjajahan moral. Meskipun demikian mahasiswa tetap harus menanamkan sikap kepahlawanan dalam mempertahankan negara ini, dan harus berdasarkan pembelaan terhadap tanah air.

Tafsir nilai-nilai kepahlawanan di Indonesia terus berkembang dari zaman ke zaman. Jika pada masa revolusi kepahlawanan identik dengan perang senjata dalam mengusir penjajah, berbeda lagi pada masa orde lama, semangat kepahlawanan identik dengan usaha-usaha untuk menuntaskan agenda revolusi. Pada saat Orde Baru, kepahlawanan identik dengan semangat pembangunan. Berbeda lagi ketika masa reformasi, kepahlawanan identik dengan upaya untuk menghapus rezim otoriter yang dinilai tidak sesuai dengan Pancasila dan berusaha membangun demokrasi. Sampai saat ini nilai-nilai kepahlawanan terus berkembang. Bila diamati nilai-nilai kepahlawanan saat ini identik dengan penataan kembali pemerintahan dan upaya pencapaian prestasi bangsa.

Akan tetapi, harus disadari bahwa nilai-nilai kepahlawanan di negeri ini juga semakin semrawut dalam bungkusan pertarungan politik, ekonomi, sosial, dan budaya yang pragmatis. Bahkan tak sedikit dari mahasiswa yang lambat laun melupakan nilai-nilai kepahlawanan dan cenderung memelihara egoistis. Tanpa sadar mahasiswa telah diperbudak oleh arus globalisasi. Ingatan tentang heroistik mahasiswa pada masa revolusi seakan hanya cerita hiburan belaka bagi bangsa Indonesia. Mereka rela berkorban melawan kolonialisme dan mempertahankan tanah air. Tidak terdengar keluhan pada perjuangan mereka, yang terdengar adalah suara-suara perjuangan yang penuh dengan semangat patriotisme.

Jelas berbeda pada masa sekarang, hal ini terlihat di sekeliling, ternyata pemahaman akan nilai-nilai kepahlawanan tampaknya sudah mulai memudar. Contoh dalam memelihara rasa nasionalisme, sering dijumpai banyak mahasiswa yang malas dan malu untuk menyanyikan lagu kebangsaannya sendiri. Para pemuda lebih menyukai lagu-lagu reggae, lagulagu yang bertemakan percintaan dan sebagainya. Sangat sedikit yang tertarik dengan lagu-lagu kebangsaan atau yang bertemakan edukasi. Dari contoh kecil tersebut sudah menandakan bahwa jiwa nasionalisme di kalangan mahasiswa mulai menurun. Tak hanya itu upacara bendera yang sudah menjadi budaya sekolah setiap hari Senin sekarang mulai memudar. Padahal, upacara merupakan salah satu usaha untuk menanamkan jiwa nasionalisme dan pendidikan karakter. Tak hanya di lingkungan sekolah, misalnya bisa dilihat di toko-toko dan di tempat tongkrongan para mahasiswa. Sebagai contoh kecil, bisa diamati kaos-kaos yang banyak dikenakan oleh para mahasiswa. Kebanyakan dari kaos tersebut berlambangkan simbol-simbol luar negeri seperti bendera Inggris, USA, 
Kanada dan sebagainya. Sangat jarang dilihat mahasiswa yang mengenakan kaos bersimbol dari negara Indonesia itu sendiri.

Di kalangan elit politik, nilai-nilai kepahlawanan nampaknya juga kian terkikis. Budaya jujur dan tanggung jawab sudah tidak diindahkan lagi. Mereka sudah tidak lagi menjadikan nilai-nilai kepahlawanan tersebut sebagai pedoman dalam membangun negara ini. Masyarakat sudah tidak asing lagi dengan berita-berita tentang kasus korupsi dan penggelapan uang, baik di kalangan pemerintah daerah maupun pusat. Budaya korupsi seakan sudah menjadi budaya para kaum elit. Tak ada lagi kejujuran dan tanggung jawab dalam mengelola negeri ini. Egoisme, oportunisme, dan hedonisme menjadi tujuan mereka duduk di bangku pemerintahan, bukan lagi bertujuan untuk kesejahteraan rakyat. Mereka tidak lagi fokus pada nilai-nilai kepahlawanan dan perjuangan dalam mempertahankan Negara Kesatuan Republik Indonesia. Sedikit dari generasi muda yang benar-benar serius dalam membentuk karakter bangsa yang adil dan sesuai dengan Pancasila.

Dalam dunia pendidikan pun nilai kepahlawanan semakin memudar, terutama di kalangan mahasiswa. Masih banyak dijumpai para mahasiswa ketika menghadapi ujian maupun kuis mereka masih mencontek. Itu berarti kejujuran dan kepercayaan diri mereka sudah hilang. Berdasarkan uraian tersebut dapat disimpulkan bahwa nilai-nilai kepahlawanan pada mahasiswa memang sudah kian meluntur. Berikut beberapa hal yang menyebabkan lunturnya nilai-nilai kepahlawanan di kalangan mahasiswa, di antaranya memudarnya pemahaman ideologi Pancasila, rapuhnya pemahaman tentang sejarah, arus globalisasi dan modernisasi, serta kemandirian atau otonomi yang kehilangan orientasi.

Dalam sebuah artikel yang ditulis oleh Agus Budiarto (September, 2012) bahwa mulai dari pelajar sampai mahasiswa di perguruan tinggi tidak menerima Pancasila sebagai dasar negara. Keprihatinan ini didasarkan adanya data dari Lembaga Ilmu Pengetahuan Indonesia (LIPI) yang mengatakan $80 \%$ mahasiswa di lima perguruan tinggi terkemuka di Jawa menolak Pancasila. Beberapa faktor yang menyebabkan memudarnya pemahaman terhadap Pancasila, antara lain (a) watak oportunis elit yang ada di lembaga Negara, (b) adanya perilaku koruptif di kalangan elit bangsa yang menjadikan mahasiswa tidak berpondasi pada nilai-nilai Pancasila lagi karena moral para elit yang tidak berorientasi pada tujuan Pancasila untuk mewujudkan keadilan sosial, (c) nilai-nilai toleransi yang diajarkan Pancasila mulai lepas dari jiwa kalangan muda, banyaknya tawuran antarpelajar maupun antarkelompok masyarakat, dan (d) pendidikan kewarganegaraan yang kurang sehingga di sekolah-sekolah saat ini sudah tidak lagi memprioritaskan mata pelajaran Pendidikan Kewarganegaraan.

Soekarno menyatakan bahwa "Bangsa yang besar adalah bangsa yang menghargai jejak-jejak para pahlawan". Mahasiswa dapat mengenal perjuangan bangsa ini dan bagaimana proses bersatunya pulau-pulau di Nusantara ini menjadi satu bangsa yang utuh di bawah semboyan "Bhinneka 
Tunggal Ika". Mahasiswa harus banyak belajar dari sejarah. Sejarah dalamnya mengandung nilai-nilai kepahlawanan dan pembelajaran di setiap kejadiannya. Namun pada kenyataannya, di negeri ini sejarah hanya tinggal catatan lusuh saja, sejarah hanya tinggal cerita kuno. Kaum muda saat ini lebih tertarik membaca status selebritis dibanding mempelajari sejarah. Lebih mengidolakan artis dibanding mengidolakan para pahlawan. Mereka hafal riwayat hidup artis favorit mereka bahkan meniru gaya hidup mereka. Namun untuk menghafal nama-nama pahlawan saja mereka tidak tahu. Hal tersebut harus menjadi perhatian semua kalangan, mengapa bisa terjadi dan bagaimana cara mengatasinya.

Globalisasi dan modernisasi membawa dampak yang sangat besar terhadap perkembangan generasi muda. Pergaulan yang tanpa batas menjadikan kaum muda lambat laun meniru gaya hidup orang barat, banyak norma yang tidak sesuai dengan karakter bangsa Indonesia. Dampak negatif yang ditimbulkan sangat menjadi perhatian semua kalangan. Merajalelanya budaya konsumtif, sikap materialistik, individualistik, kriminalitas, dan kenakalan remaja menjadi perhatian khusus. Indonesia juga sedang dihadapkan pada masalah yang sangat memprihatinkan. Negara Indonesia dihadapkan pada mental dan moral pemuda yang kian bobrok. Banyaknya kasus hukum yang dihadapkan pada para pemuda seperti seks bebas, narkoba, kriminalitas, dan tawuran. Perjuangan pahlawan telah ternodai oleh ulah kaum muda yang tidak bertanggung jawab dalam menghadapi arus zaman.

Dalam pengendaliannya banyak yang sibuk mengurusi etnis masingmasing, tanpa memperhitungkan kepentingan nasional. Ada pun upayaupaya yang dapat dilakukan untuk penanaman nilai-nilai kepahlawanan pada generasi muda khususnya mahasiswa, antara lain (a) penyadaran, pengenalan dan penafsiran kembali nilai-nilai Pancasila sebagai nilai yang harus di perjuangkan, (b) mengenalkan dan menghayati sejarah, (c) pendidikan karakter, (d) pemusatan otonomi daerah yang harus didasarkan pada wawasan kebangsaan, yang harus didasari oleh pemikiran bersama untuk mewujudkan cita-cita bangsa, dan (e) pemusatan pendidikan yang dilandasi dengan kesadaran mencapai tujuan pengabdian kepada negara.

Ada satu peristiwa di suatu pelatihan kepemudaan di salah satu perguruan tinggi penulis menangkap suatu peristiwa yang sangat menarik perhatian, khususnya untuk generasi muda. Pada kesempatan tersebut yang kebetulan dihadiri oleh DPR seorang mahasiswa diberi kesempatan untuk menyebutkan Pancasila. Akan tetapi yang terjadi mahasiswa tersebut tidak dapat menyebutkan secara lengkap. Ini adalah sebagian contoh kecil potret anak bangsa. Ironisnya kejadian seperti ini dialami oleh kalangan terpelajar. Maka dari itu, sangat diperlukan adanya pengenalan kembali nilai-nilai Pancasila pada generasi muda saat ini. Jika dibiarkan maka mental pemuda saat akan semakin terpuruk. Negara ini akan dipegang oleh tangan-tangan yang tidak mempunyai fondasi. Pengenalan tersebut dapat dilakukan melalui 
pendidikan kewarganegaraan, pengenalan budaya, dan karakter bangsa Indonesia.

Moeldoko mengatakan "generasi muda sebagai agen perubahan yang terjadi pada mahasiswa, generasi muda masih dapat dikatakan wajar selagi mereka bisa memahami konsep wawasan kebangsaan dan menghargai sejarah bangsa sendiri". Beliau juga mengungkapkan "generasi muda adalah agen perubahan maka harus paham dan jangan lupakan sejarah" (Moeldoko: 2012). Jika di tilik lebih dalam lagi, melalui sejarah sebuah bangsa bisa berbenah diri dari kesemrawutan. Namun sayangnya saat ini sejarah bukan hal yang menarik untuk dipelajari di kalangan kaum muda. Mata pelajaran sejarah mulai tenggelam dan sudah tidak diprioritaskan. Jika diamati sekarang sistem pendidikan di bangku sekolah lebih memprioritaskan mata pelajaran seperti matematika, fisika dan sebagainya. Berdasarkan pengakuan beberapa siswa jumlah jam yang digunakan untuk mata pelajaran sejarah sangat minim. Ada yang satu minggu hanya mendapat jatah satu jam pelajaran yang dalam satu jam hanya berdurasi 40 menit. Untuk itu harus berupaya untuk terus meningkatkan dan menghidupkan kembali pengetahuan dan penghayatan tentang sejarah. Sejarah merupakan salah satu fondasi untuk menentukan sikap dan membentuk karakter. Melalui sejarah, manusia dapat belajar berbagai keutamaan, kelebihan, dan kesuksesan generasi sebelumnya, sehingga dapat diikuti oleh generasi muda. Sebaliknya, sejarah dapat mengetahui kegagalan yang dialami generasi sebelumnya dan mencermati sebab-sebab kegagalan tersebut, sehingga dapat melakukan upaya agar terhindar dari kesalahan serupa.

Pendidikan karakter merupakan fondasi untuk menentukan baik buruknya jati diri generasi muda yang akan memegang masa depan bangsa. Jika generasi mudanya mempunyai karakter yang berkualitas, yang sesuai dengan jati diri bangsa, tidak mustahil negeri ini akan adil dan makmur. Sebaliknya, jika karakter pemuda bobrok maka negara juga akan ikut bobrok. Untuk itu, diperlukan adanya pendidikan karakter pada genersi muda. Pendidikan ini dapat dimulai dengan menanamkan sikap-sikap yang terpuji pada diri generasi muda sejak dini, seperti kejujuran, tanggung jawab, berani, ikhlas, dan mempunyai etos kerja yang baik.

Adapun langkah-langkah efektif guna menanamkan nilai-nilai kepahlawanan di lingkungan mahasiswa agar memiliki peran dalam membangun bangsa dan negara Indonesia adalah (a) menanamkan rasa cinta tanah air dan demokratis melalui lomba-lomba berbasis wawasan kebangsaan dan semacamnya bagi mahasiswa dari berbagai perguruan tinggi, seperti lomba penulisan opini, karya tulis, teater, cerdas cermat, menyanyikan lagu kebangsaan NKRI, dan lain-lain; (b) menanamkan sikap rela berkorban, bertanggung jawab serta kerja keras melalui program kompetisi dinamika kelompok bagi mahasiswa yang bertema kebangsaan Indonesia dengan diatur sedemikian rupa hingga mencapai tujuan utama yaitu tertanamnya sikap rela berkorban (yaitu ditandai dengan rela berkorbannya anggota kelompok bagi 
kebaikan dan keberhasilan kelompok), bertanggung jawab (yaitu ditandai dengan setiap anggota kelompok mampu bertanggung jawab atas masingmasing tugasnya) serta kerja keras (yaitu ditandai dengan kerja keras anggota kelompok demi kemenangan kompetisi; (c) menanamkan rasa kemandirian dalam diri mahasiswa melalui peningkatan mutu dan kualitas pendidikan, misalnya melalui kegiatan yang dilakukan berbasis melatih kemandirian mahasiswa, misalnya kegiatan KKN dan PPL; (d) menanamkan kejujuran dalam diri mahasiswa hingga membentuk sebuah karakter yang berbudi luhur hendaknya dimulai sejak dini, yaitu target tepat sasaran adalah para generasi muda khususnya mahasiswa

Kejujuran dimulai dalam jenjang pendidikan formal (sekolah) khususnya dalam proses pembelajaran. Kecurangan dan ketidakjujuran tersebut berawal dari proses perolehan nilai yang diambil dari ulangan harian maupun ujian-ujian semacamnya. Untuk menciptakan karakter bangsa yang jujur, alangkah baiknya tenaga pendidik lebih memperketat pengawasannya pada saat ujian berlangsung serta memberikan nilai tambah bagi siswa yang benar-benar jujur dalam mengerjakan ujian tersebut sehingga siswa tidak takut untuk jujur dengan tekanan mendapat nilai buruk dibanding siswa yang tidak jujur.

Melihat fenomena masyarakat yang selalu mengalami perubahan karena perkembangan teknologi komunikasi dan informasi, maka diperlukan pahlawan-pahlawan masa kini yang peka, tanggap, jujur, dan bertanggung jawab serta mampu menangani permasalahan bangsa. Di Indonesia sendiri nilai-nilai kepahlawanan masih sangat rendah. Nilai-nilai kepahlawanan hanya sampai pada hafalan saja, sehingga belum sampai pada pengamalan dan penghayatan dalam kehidupan sehari-hari. Ini menunjukan masih sangat minimnya penghayatan tentang nilai-nilai kepahlawanan.

Ada cara sederhana yang dapat dilakukan oleh para kaum muda khususnya mahasiswa dalam mengimplementasikan nilai-nilai kepahlawanan. Tidak harus mengangkat senjata di medan perang, namun dapat diimplementasikan pada aktivitas sehari-hari yang dilaksanakan sesuai profesi yang dijalani dengan penuh tanggung jawab. Jika nilai-nilai tersebut diterapkan dengan baik maka hasil yang dicapai pun akan baik. Sebagai mahasiswa, nilai-nilai kepahlawanan bisa diimplementasikan dengan berlaku jujur, semangat belajar, disiplin serta mentaati tata tertib. Bagi para elit politik yang duduk di bangku pemerintah, maka bisa diterapkan juga budaya jujur, menghindarkan diri dari perilaku KKN. Bagi para pengusaha, dapat menerapkan jiwa kreativitas yang akan menguatkan ekonomi negara. Sifat luhur para pahlawan harus senantiasa melekat pada generasi muda dalam upaya pencapaian cita-cita. Sifat-sifat luhur tersebut merupakan tonggak berdirinya negara yang adil dan makmur. 


\section{Penutup}

Menumbuhkan nilai-nilai kepahlawanan merupakan upaya menimbulkan suatu sikap dan perilaku perjuangan yang mempunyai mutu dan jasa pengabdian serta pengorbanan terhadap bangsa dan negara. Ada pun nilai-nilai kepahlawanan yang dimaksud adalah rela berkorban, cinta tanah air, kerja keras, keteladanan, kejujuran, demokratis, mandiri, dan bertanggung jawab yang harus diintegrasikan dalam kehidupan sehari-hari.

Mahasiswa merupakan salah satu bagian dari masyarakat dan pemerintah yang ikut ambil bagian bela negara. Wadah penyaluran potensi mahasiswa untuk ikut serta dalam bela negara melalui Pendidikan Pancasila dan Pendidikan Kewarganegaraan serta menyisipkan pendidikan kesadaran bela negara secara sistematik dan berkelanjutan dalam setiap pertemuan di ruang kuliah sehingga menimbulkan rasa kesadaran bela negara dengan semangat, disiplin, dan jiwa nasionalisme yang tinggi.

Adapun langkah-langkah efektif guna menumbuhkan nilai-nilai kepahlawanan di lingkungan mahasiswa adalah: menanamkan rasa cinta tanah air dan demokratis melalui lomba-lomba berbasis wawasan kebangsaan dan semacamnya bagi mahasiswa dari berbagai perguruan tinggi; menanamkan sikap rela berkorban, bertanggung jawab serta kerja keras melalui program kompetisi dinamika kelompok bagi mahasiswa yang bertema kebangsaan Indonesia; menanamkan rasa kemandirian dalam diri mahasiswa melalui peningkatan mutu dan kualitas pendidikan melalui kegiatan KKN dan PPL; dan menanamkan kejujuran dalam diri mahasiswa hingga membentuk karakter yang berbudi luhur hendaknya dimulai sejak dini.

Nilai-nilai kepahlawanan sejatinya menjadi salah satu identitas nasionalisme warga negara tanpa terkecuali, khususnya mahasiswa. Oleh karena itu, mahasiswa hendaknya terlibat aktif serta mengambil peran sesuai dengan kedudukannya masing-masing guna mewujudkan identitas nilai-nilai kepahlawanan tersebut. Dalam koridor tersebut, penulis memberikan saran: (a) kampus menjunjung tinggi nilai-nilai akademisi; pendidikan, penelitian, dan pengabdian kepada masyarakat oleh karena itu nilai-nilai kepahlawanan tidak hanya terpaku pada domain tertentu saja tetapi meliputi keseluruhan dari nilai-nilai akademisi, yang mana perguruan tinggi hendaknya menerapkan konsep nilai-nilai kepahlawanan secara dinamis, seperti; penguatan mata kuliah Pendidikan Kewarganegaraan, mengikuti kegiatan yang meningkatkan rasa nasionalisme dan wawasan kebangsaan, atau kegiatan serupa lainnya yang merepresentasikan wujud nilai-nilai kepahlawanan; dan (b) mahasiswa selaku agent of change secara nyata mengedepankan sikap nasionalisme yang konkret dengan terlibat secara aktif dan konsisten dalam wujud nilai-nilai kepahlawanan sebagaimana disebutkan di atas, yang tidak hanya dibatasi oleh ruang dan tempat yang ada di kampus semata tetapi juga tempat-tempat lainnya, seperti rumah, indekos, asrama, dan mal. 


\section{Daftar Acuan}

Bahri, Efri S. 2013. Hari-hari Mahasiswa: Kiprah dan Agenda Pergerakan Mahasiswa. Jakarta: FAM Publishing.

Departemen Pendidikan Nasional. 2003. Kamus Besar Bahasa Indonesia. Jakarta: Balai Pustaka.

Rianto, Subandi, dkk. 2012. Mahasiswa: Menggagas Kebangkitan Indonesia. Surabaya: BEM Universitas Airlangga.

Sumarsono, S. et.al. 2001. Pendidikan Kewarganegaraan. Jakarta: Gramedia Pustaka Utama.

Ricklefs, M.C. 1998. Sejarah Indonesia Modern 1200-2008. Jakarta: Serambi Ilmu Semesta.

Horton, Paul B. \& Hunt, Chester C. 1999. Sosiologi Edisi Keenam. Terjemahan. Jakarta: Penerbit Erlangga.

Saunders, W.B. 1977. Health Proffesional's Planner. United States of America: Rush Medical Center.

Sudarmanto, J.B. 2006. Jejak-Jejak Pahlawan Perekat Kesatuan Bangsa Indonesia. Jakarta: Grasindo.

Schulte, Henk. 2008. Perspektif Baru Penulisan Sejarah Indonesia. Terjemahan. Jakarta: Yayasan Obor Indonesia.

Tim Penyusun KBBI. 2005. Kamus Besar Bahasa Indonesia. Jakarta: Pusat Bahasa Departemen Pendidikan Nasional Republik Indonesia. 